\title{
An initial investigation replacing fish meal with a commercial fermented soybean meal product in the diets of juvenile rainbow trout
}

\author{
Michael E. Barnes ${ }^{1^{*}}$, Michael L. Brown ${ }^{2}$, Kurt A. Rosentrater $^{3}$, Jason R. Sewell ${ }^{4}$ \\ ${ }^{1}$ South Dakota Department of Game, Fish and Parks, McNenny State Fish Hatchery, Spearfish, USA; \\ *Corresponding Author: mike.barnes@state.sd.us \\ ${ }^{2}$ Department of Wildlife and Fisheries Sciences, South Dakota State University, Brookings, USA \\ ${ }^{3}$ Department of Agricultural and Biosystems Engineering, Iowa State University, Ames, USA \\ ${ }^{4}$ Nutraferma Inc., North Sioux City, USA
}

Received 16 July 2012; revised 24 August 2012; accepted 8 September 2012

\begin{abstract}
The inclusion of PepSoyGen (PSG), a commercially-available fermented soybean meal product, was evaluated with juvenile rainbow trout, Oncorhynchus mykiss in an initial 70-day feeding trial, with a supplemental trial involving a subset of the experimental diets continuing for an additional $\mathbf{4 0} \mathrm{d}$. Six diets containing $0 \%, \mathbf{1 0} \%, \mathbf{2 0 \%}$, $30 \%, 40 \%$, or $50 \%$ PSG, with the PSG directly replacing fish meal, were used in the first trial. There were no significant differences in weight gain or feed conversion ratio between the fish meal-based control diet and diets containing up to $30 \%$ PSG. However, weight gain was significantly reduced and feed conversion ratio significantly increased with the $40 \%$ and $50 \%$ PSG diets. No health assessment differences were observed in fish receiving any of the diets, and no evidence of gross gut inflammation was evident. There were no significant differences in weight gain or feed conversion ratio among the four dietary treatments ranging from $0 \%$ to $30 \%$ PSG which were fed for an additional $40 \mathrm{~d}$ after the initial 70-d trial (110 days total). Based on these results, juvenile rainbow trout diets can contain up to $30 \%$ PSG without any loss of rearing performance, thereby replacing at least $60 \%$ of the fish meal.
\end{abstract}

Keywords: Rainbow Trout; Fermented Soybean Meal; PepSoyGen; Oncorhynchus mykiss; Diet; Alternative Proteins

\section{INTRODUCTION}

The primary protein source in hatchery feed for rain- bow trout Oncorhynchus mykiss and other carnivorous salmonids is typically fish meal [1-3]. However, the limited supply of fish meal has not expanded in unison with the growth of global aquaculture, resulting in dramatic price increases [4-6]. Thus, there is an obvious need for lower-cost, sustainable protein sources to replace fish meal in salmonid diets [6].

A variety of plant proteins have been investigated as possible fish meal replacements for salmonids, with soybean meal most commonly used $[7,8]$. Inclusion rates for soybean meal in salmonid diets have typically been low because of the presence of trypsin inhibitors, lectins, saponins, poorly digestible carbohydrates (oligo- and polysaccharides), and other anti-nutritional factors [9-12]. Soybean meal in rainbow trout diets produces welldocumented deleterious effects on the distal intestine, such as morphological changes and subacute enteritis [12-19], as well as changes to intestinal microbial communities [15,16,18], and hepatic morphology [12]. Similar effects have been reported in Atlantic salmon Salmo salar [20-23].

Many of the negative effects associated with soybean meal can be reduced or eliminated with further processing [11]. Anti-nutritional factors can be reduced during feed extrusion $[24,25]$ and by infra-red micronization [24]. Processed (solvent and heat treated) soy protein concentrates have lower concentrations of many antinutritional factors [26]. Fermentation may also improve the suitability of soybean meal as an alternative protein source in fish diets [11], although few studies have been conducted with fish in general or rainbow trout specifically until very recently. Fermented soybean meal has been used in the diets of parrot fish Oplegnathus fasciatus [27], red sea bream Pagrus major [28], pompano Trachinotus ovatus [29], and Japanese flounder Paralichthys olivaceus [30,31]. Yamamoto et al. [32] noted that 
soybean meal fermented primarily by Bacillus spp. for $10 \mathrm{~h}$ with $30 \%$ water addition did not produce any changes in intestinal morphology when used in non-fish meal based rainbow trout diets. They also suggested that fermented soybean meal had the potential to become the dominant protein source in rainbow trout composite diets.

PepSoyGen $^{\circledR}$ (PSG; Nutraferma Inc. of North Sioux City, SD, USA) is a soybean meal fermentation feed product manufactured via a proprietary process incorporating Aspergillus spp. and Bacillus spp. It has not previously been evaluated for use as a possible fish meal replacement in aquaculture diets. Thus, the objective of this study was to conduct an initial investigation into the incorporation of PSG into the diets of juvenile rainbow trout.

\section{MATERIAL AND METHODS}

\subsection{Location and Fish Culture}

The study was conducted at McNenny State Fish Hatchery, Spearfish, SD, USA, using degassed and aerated well water at a constant temperature of $11 \mathrm{C}$ (total hardness as $\mathrm{CaCO}_{3}, 360 \mathrm{mg} / \mathrm{L}$; alkalinity as $\mathrm{CaCO}_{3}, 210$ $\mathrm{mg} / \mathrm{L}$; pH, 7.6; total dissolved solids, $390 \mathrm{mg} / \mathrm{L})$. Flow rates in each tank were set at $40 \mathrm{~L} / \mathrm{min}$.

During the primary trial, approximately 200 McConaughy strain juvenile rainbow trout (initial weight $6.1 \pm 0.5 \mathrm{~g}$, length $85 \pm 2 \mathrm{~mm}$, mean $\pm \mathrm{SE}$ ) were randomly selected and placed into each of 24 fiberglass circular tanks (1.8 m diameter, $0.6 \mathrm{~m}$ depth) on July 21 , 2009. Feeding commenced the following day and continued for 70 days until the end of the trial. Tanks were each loaded based on weight (as-is, or wet, basis) to the nearest $1.0 \mathrm{~g}$, and fish numbers were estimated. Feeding amounts for the tanks were determined by the hatchery constant (HC) method [33], with a planned feed conversion of 1.1 and a maximum growth rate of $0.065 \mathrm{~cm} /$ day, which was based on the maximum growth rate of juvenile McConaughy strain rainbow trout historically observed at McNenny State Fish Hatchery [34]. Feed amounts were updated daily. Feed was uniformly dispensed from 07:00 to 19:00 in each tank using automatic EWOS 505 feeders (Norco-plast AB, Sweden), which were electronically programmed to release small amounts of feed for a duration of $2 \mathrm{~min}$ at 20-min intervals. All feed dispensed and fish mortalities were recorded daily for each tank. Percent mortality was determined by dividing the number of fish that died during the trial by the total number of fish $(n=200)$ initially present in each tank.

\subsection{Diets and Chemical Analysis}

The 24 tanks were randomly assigned to one of six different diets (Table 1); with four replicate tanks receiving the same diet. These six diets contained $0 \%, 10 \%$, $20 \%, 30 \%, 40 \%$, or $50 \%$ PSG, with the PSG incrementally replacing fish meal as the primary protein source. Feeds were manufactured via extrusion. Because the objective of this study was to evaluate PSG as a direct fishmeal replacement, the diets were not formulated to be isonitrogenous or isocaloric. The resulting pellets were analyzed according to AOAC [35] method 2001.11 for protein, method 2003.5 (modified by substituting petroleum ether for diethyl ether) for crude lipid, and AACC [36] method 08-03 for ash content. The protein and lipid amounts obtained by these methods were multiplied by their respective physiological fuel values of $23.6 \mathrm{~J}$ and $39.5 \mathrm{~J}$ [37], respectively, to obtain estimated gross energy values.

\subsection{Data Collection}

At the end of the primary feeding trial, total tank weights were recorded to the nearest $1.0 \mathrm{~g}$, with weight gain calculated by subtracting the initial weight from the final weight for each tank. Feed conversion ratio for each

Table 1. Ingredients composition (\%) and chemical analysis of the diets used.

\begin{tabular}{lcccccc}
\hline & \multicolumn{5}{c}{ Diet (\%) } \\
\cline { 2 - 7 } Ingredients & 1 & 2 & 3 & 4 & 5 & 6 \\
\hline Herring meal $^{\mathrm{a}}$ & 50 & 40 & 30 & 20 & 10 & 0 \\
PepSoyGen $^{\mathrm{b}}$ & 0 & 10 & 20 & 30 & 40 & 50 \\
Whole weat flour $^{\mathrm{c}}$ & 15 & 15 & 15 & 15 & 15 & 15 \\
Corn gluten meal $^{\mathrm{d}}$ & 15 & 15 & 15 & 15 & 15 & 15 \\
Menhaden oil $^{\mathrm{e}}$ & 12.0 & 12.8 & 13.5 & 14.3 & 15.0 & 15.8 \\
Celufil $^{\mathrm{f}}$ & 5.5 & 4.7 & 4.0 & 3.2 & 2.5 & 1.7 \\
Vitamin and mineral mix $^{\mathrm{g}}$ & 2 & 2 & 2 & 2 & 2 & 2 \\
Vitamin C (Stay-C) $^{\mathrm{h}}$ & 0.5 & 0.5 & 0.5 & 0.5 & 0.5 & 0.5 \\
Total & 100 & 100 & 100 & 100 & 100 & 100 \\
Chemical analysis (\% dry basis) $^{\mathrm{i}}$ & & & & & \\
Crude protein $_{\text {Crude lipid }}^{52.0}$ & 50.5 & 48.1 & 46.3 & 44.1 & 43.0 \\
Ash & 15.3 & 15.5 & 15.8 & 15.8 & 16.0 & 14.2 \\
Gross energy (kJ/g) & 18.32 & 18.04 & 17.59 & 17.17 & 16.73 & 15.76 \\
\hline
\end{tabular}

${ }^{a}$ Lortscher Agri Service, Inc., Bern, Kansas, USA; ${ }^{\mathrm{b}}$ Nutraferma, North Sioux City, South Dakota, USA; 'B Bob's Red Mill Natural Foods, Inc., Milwaukie, Oregon, USA; ${ }^{\mathrm{d}}$ Consumers Supply Distributing Company, Sioux City, Iowa, USA; 'Omega Protein, Inc., Houston, Texas, USA; ' USB Corporation, Cleveland, Ohio, USA: ${ }^{g}$ Lasi Fish Premix, NB-8055, Lortscher Agri Service,

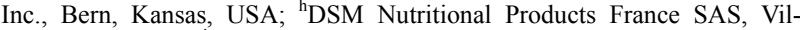

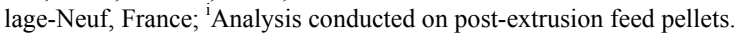


tank was calculated by dividing the total amount of food fed by the total weight gain. In addition to total tank measurements, five fish were randomly selected from each tank and individually weighed to the nearest $1.0 \mathrm{~g}$ and measured (total length) to the nearest $1.0 \mathrm{~mm}$. Fish health profiles, based on a modification of Goede and Barton [38], Adams et al. [39], and Barton et al. [40], were completed using the score sheet described in Table 2. Liver weights were also recorded to the nearest $1.0 \mathrm{mg}$ and the hepatosomatic index (HSI) was determined using the formula: HSI $(\%)=100 \times($ liver weight/whole fish weight) [41].

\subsection{Apparent Digestability}

Apparent protein digestability was determined using a direct method [42]. Digesta was removed from five fish per tank at the end of the trial. Each fish was dissected and the last $1.0 \mathrm{~cm}$ of the distal end of the intestine was gently squeezed to remove the contents. Harvested digesta from the five fish per tank was pooled and flash frozen on dry ice prior to analysis. Protein analysis was conducted using AOAC [35] method 990.03. Apparent protein digestability was calculated using the formula: apparent protein digestability $=$ (protein in the diet protein in the digesta)/protein in the diet [37].

Table 2. Criteria used at the end of the study for visual fish health observations (based on Goede and Barton [38], Adams et al. [39], and Barton et al. [40]).

\begin{tabular}{|c|c|c|}
\hline Structure of Tissues & Rating Criteria & Numeric Rating \\
\hline Eyes & $\begin{array}{l}\text { Normal } \\
\text { Abnormal }\end{array}$ & $\begin{array}{l}0 \\
1\end{array}$ \\
\hline Fat & $\begin{array}{l}\text { None } \\
<50 \% \text { of gut covered } \\
>50 \% \text { of gut covered } \\
100 \% \text { of gut covered }\end{array}$ & $\begin{array}{l}0 \\
1 \\
2 \\
3\end{array}$ \\
\hline Fins & $\begin{array}{l}\text { No erosion } \\
\text { Light erosion } \\
\text { Moderate erosion } \\
\text { Severe erosion }\end{array}$ & $\begin{array}{l}0 \\
1 \\
2 \\
3\end{array}$ \\
\hline Gills & $\begin{array}{l}\text { Normal } \\
\text { Clubbed, frayed, or discolored }\end{array}$ & $\begin{array}{l}0 \\
1\end{array}$ \\
\hline Gut & $\begin{array}{l}\text { Normal } \\
\text { Slight inflammation } \\
\text { Moderate inflammation } \\
\text { Severe inflammation }\end{array}$ & $\begin{array}{l}0 \\
1 \\
2 \\
3\end{array}$ \\
\hline Kidney & $\begin{array}{l}\text { Normal } \\
\text { Abnormal }\end{array}$ & $\begin{array}{l}0 \\
1\end{array}$ \\
\hline Liver & $\begin{array}{l}\text { Normal } \\
\text { Abnormal }\end{array}$ & $\begin{array}{l}0 \\
1\end{array}$ \\
\hline Pseudobranchs & $\begin{array}{l}\text { Normal } \\
\text { Abnormal }\end{array}$ & $\begin{array}{l}0 \\
1\end{array}$ \\
\hline Opercles & $\begin{array}{l}\text { Normal } \\
\text { Short }\end{array}$ & $\begin{array}{l}0 \\
1\end{array}$ \\
\hline Spleen & $\begin{array}{l}\text { Normal } \\
\text { Cysts or enlarged }\end{array}$ & $\begin{array}{l}0 \\
1\end{array}$ \\
\hline
\end{tabular}

\subsection{Fillet Composition}

At the end of the primary feeding trial, five fish per tank were also euthanized; muscle fillets were then removed and flash frozen for determination of fillet composition. The fillets from each tank were pooled and analyzed for crude protein levels with a TruSpec CNS combustion analyzer (LECO Corp., St. Joseph, Michigan) using AOAC [35] method 992.15. AOAC [35] method 948.15, which used acid hydrolysis with a 50:50 mix of diethyl ether and petroleum ether for extraction, was used for fat analysis. Moisture was determined by loss on drying using AOAC [35] method 952.08.

\subsection{Secondary Continuing Trial}

After data collection at the end of the initial 70-day trial, an unexpected opportunity occurred whereby a limited number of hatchery tanks became available for further experimentation. Only 12 tanks were used in this secondary trial, with each tank containing approximately 115 fish. The 12 tanks were assigned to one of four diets used in the initial trial $(0 \%, 10 \%, 20 \%$, or $30 \%$ PSG), with three replicate tanks receiving the same diet. Fish remained on the diet they had consumed previously in the primary trial. This secondary trial started on October 1, 2009, and ran for 40 days. Thus, in combination with the prior trial, the trout were on their respective diets for 110 days. Because this secondary trial was not initially planned, only rearing data were collected; no fish health data or fillet composition data was obtained.

\subsection{Statistical Analysis of Data}

Data were analyzed using the SPSS version 9.0 statistical analysis program (SPSS, Chicago, IL, USA) with significance predetermined at $P<0.05$. One-way analysis of variance (ANOVA) was conducted, and if the treatments were significantly different, pairwise mean comparisons were performed using the Tukey HSD test [43]. All mortality percentage data were arcsine-square root transformed prior to analysis to stabilize the variances [43].

\section{RESULTS}

\subsection{Primary Trial}

There were no significant differences in total tank ending weights or weight gain among the tanks of rainbow trout receiving the fish meal control or diets containing $10 \%, 20 \%$, or $30 \%$ PSG (Table 3). Total tank ending weights and weight gain did decrease significantly for fish receiving diets containing 40\% PSG, with an additional significant decrease observed at the 50\% inclusion level. Feed conversion ratio followed a similar 
pattern, except for that the results produced by the $40 \%$ PSG diet were not significantly different than those observed in any of the lower PSG concentrations. Mortality was minimal and not significantly different among any of the treatments.

Liver weights and the hepatosomatic index values were significantly different among the dietary treatments, with the smallest values observed in the fish receiving $50 \%$ dietary PSG (Table 4). None of the other fish health values varied significantly among the fish receiving any of the diets. There was no gross visible gut inflammation observed in any fish either.

Fillet protein percentages were significantly affected by the diets used in this study (Table 5). The fish fed diets with $50 \%$ PSG had $18.0 \%$ fillet protein content, which was significantly less than the $19.2 \mathrm{~g} \%$ protein levels in the fillets from fish fed the control or $10 \%$ diets. There was no significant difference in fillet protein composition among fish receiving from $0 \%$ to $40 \%$ dietary PSG however. There were also no significant differences detected in fillet moisture, lipid, or ash contents among any diet treatments.

Table 3. Mean $(+\mathrm{SE})$ rearing data values, including feed conversion ratio $\left(\mathrm{FCR}^{\mathrm{a}}\right)$, for tanks of rainbow trout receiving one of six different diets containing incremental amounts of PepSoyGen (PSG). Means with different letters in the same row differ significantly $(P<0.05, \mathrm{~N}=4)$.

\begin{tabular}{|c|c|c|c|c|c|c|}
\hline Diet & 1 & 2 & 3 & 4 & 5 & 6 \\
\hline PSG (\%) & 0 & 10 & 20 & 30 & 40 & 50 \\
\hline End weight (g) & $5694 \pm 88^{a}$ & $5965 \pm 128^{\mathrm{a}}$ & $5783 \pm 97^{\mathrm{a}}$ & $5402 \pm 39^{\mathrm{a}}$ & $4656 \pm 173^{b}$ & $3603 \pm 49^{c}$ \\
\hline Gain (g) & $4388 \pm 88^{\mathrm{a}}$ & $4659 \pm 128^{a}$ & $4477 \pm 97^{\mathrm{a}}$ & $4096 \pm 39^{\mathrm{a}}$ & $3350 \pm 173^{b}$ & $2297 \pm 490^{\mathrm{c}}$ \\
\hline Gain (\%) & $336 \pm 7$ & $357 \pm 10$ & $343 \pm 7$ & $314 \pm 3$ & $256 \pm 13$ & $176 \pm 38$ \\
\hline Food fed (g) & 3838 & 3838 & 3838 & 3838 & 3838 & 3838 \\
\hline FCR & $0.88 \pm 0.02^{\mathrm{a}}$ & $0.83 \pm 0.02^{\mathrm{a}}$ & $0.86 \pm 0.02^{\mathrm{a}}$ & $0.94 \pm 0.01^{\mathrm{a}}$ & $1.15 \pm 0.06^{\mathrm{ab}}$ & $2.06 \pm 0.62^{\mathrm{c}}$ \\
\hline Mortality (\%) & $0.13 \pm 0.13$ & 0 & $0.25 \pm 0.14$ & $0.63 \pm 0.32$ & $0.50 \pm 0.20$ & $1.88 \pm 1.39$ \\
\hline
\end{tabular}

${ }^{\mathrm{a}} \mathrm{FCR}=$ feed conversion ration $=$ total food fed/total weight gain.

Table 4. Mean $( \pm \mathrm{SE})$ Individual fish lengths, weights, condition factors $(\mathrm{K})^{\mathrm{a}}$, liver weights, hepatosomatic index values $(\mathrm{HSI})^{\mathrm{b}}$, and fish health assessments ${ }^{\mathrm{c}}$ of rainbow trout fed diets containing incremental amounts of PepSoyGen (PSG). Means with different letters in the same row differ significantly $(P<0.05, \mathrm{~N}=4)$.

\begin{tabular}{|c|c|c|c|c|c|c|}
\hline Diet & 1 & 2 & 3 & 4 & 5 & 6 \\
\hline PSG (\%) & 0 & 10 & 20 & 30 & 40 & 50 \\
\hline Length (mm) & $121 \pm 5$ & $130 \pm 1$ & $133 \pm 3$ & $130 \pm 4$ & $125 \pm 5$ & $115 \pm 4$ \\
\hline Weight (g) & $21 \pm 2$ & $26 \pm 1$ & $28 \pm 2$ & $26 \pm 2$ & $24 \pm 3$ & $18 \pm 2$ \\
\hline $\mathrm{K}^{1}$ & $1.16 \pm 0.06$ & $1.15 \pm 0.02$ & $1.14 \pm 0.04$ & $1.12 \pm 0.02$ & $1.15 \pm 0.03$ & $1.08 \pm 0.02$ \\
\hline Liver Weight (g) & $0.23+0.04^{\mathrm{a}}$ & $0.28+0.03^{\mathrm{a}}$ & $0.29+0.04^{\mathrm{a}}$ & $0.27+0.03^{\mathrm{a}}$ & $0.23+0.04^{\mathrm{ab}}$ & $0.16+0.04^{b}$ \\
\hline $\mathrm{HSI}^{2}$ & $1.07+0.09^{\mathrm{a}}$ & $1.02+0.12^{\mathrm{ab}}$ & $1.01+0.09^{\mathrm{ab}}$ & $0.98+0.07^{\mathrm{av}}$ & $0.91+0.04^{\mathrm{ab}}$ & $0.83+0.15^{\mathrm{b}}$ \\
\hline \multicolumn{7}{|l|}{ Health Assessment } \\
\hline Eyes & $0.0 \pm 0.0$ & $0.0 \pm 0.0$ & $0.0 \pm 0.0$ & $0.0 \pm 0.0$ & $0.0 \pm 0.0$ & $0.0 \pm 0.0$ \\
\hline Fat & $3.0 \pm 0.0$ & $3.0 \pm 0.1$ & $2.9 \pm 0.2$ & $2.9 \pm 0.1$ & $3.0 \pm 0.0$ & $2.5 \pm 0.3$ \\
\hline Fins & $0.6 \pm 0.1$ & $0.6 \pm 0.1$ & $0.8 \pm 0.1$ & $0.7 \pm 0.2$ & $1.0 \pm 0.1$ & $1.0 \pm 0.1$ \\
\hline Gills & $0.9 \pm 0.1$ & $1.0 \pm 0.1$ & $0.9 \pm 0.1$ & $1.0 \pm 0.1$ & $1.0 \pm 0.1$ & $0.6 \pm 0.1$ \\
\hline Gut & $0.0 \pm 0.0$ & $0.0 \pm 0.0$ & $0.0 \pm 0.0$ & $0.0 \pm 0.0$ & $0.0 \pm 0.0$ & $0.0 \pm 0.0$ \\
\hline Kidney & $0.0 \pm 0.0$ & $0.0 \pm 0.0$ & $0.0 \pm 0.0$ & $0.0 \pm 0.0$ & $0.0 \pm 0.0$ & $0.0 \pm 0.0$ \\
\hline Liver & $0.0 \pm 0.0$ & $0.1 \pm 0.1$ & $0.0 \pm 0.0$ & $0.2 \pm 0.2$ & $0.0 \pm 0.0$ & $0.1 \pm 0.1$ \\
\hline Pseudobranchs & $0.0 \pm 0.0$ & $0.0 \pm 0.0$ & $0.0 \pm 0.0$ & $0.0 \pm 0.0$ & $0.0 \pm 0.0$ & $0.0 \pm 0.0$ \\
\hline Opercles & $0.1 \pm 0.1$ & $0.2 \pm 0.1$ & $0.2 \pm 0.1$ & $0.2 \pm 0.1$ & $0.4 \pm 0.2$ & $0.2 \pm 0.2$ \\
\hline Spleen & $0.0 \pm 0.0$ & $0.0 \pm 0.0$ & $0.0 \pm 0.0$ & $0.2 \pm 0.2$ & $0.0 \pm 0.0$ & $0.0 \pm 0.0$ \\
\hline
\end{tabular}

${ }^{\mathrm{a}}$ Condition factor $(\mathrm{K})=105 \times($ weight $) /\left(\right.$ length $\left.{ }^{3}\right) ;{ }^{\mathrm{b}}$ Hepatosomatic index $(\mathrm{HSI})=100 \times($ liver weight/body weight $) ;{ }^{\mathrm{c}}$ Fish health assessments rating system described in Table 2. 
Table 5. Fillet composition of rainbow trout fed one of six diets containing incremental amounts of PepSoyGen (PSG). Means with different letters in the same row differ significantly $(P<0.05, \mathrm{~N}=4)$.

\begin{tabular}{ccccccc}
\hline Diet & 1 & 2 & 3 & 4 & 5 & 6 \\
\hline PSG (\%) & 0 & 10 & 20 & 30 & 40 & 50 \\
Water (\%) & $74.7 \pm 0.1$ & $72.1 \pm 2.2$ & $72.6 \pm 0.6$ & $73.1 \pm 1.1$ & $73.2 \pm 0.1$ & $73.9 \pm 0.7$ \\
Crude protein (\%) & $19.2 \pm 0.2^{\mathrm{a}}$ & $19.2 \pm 0.1^{\mathrm{a}}$ & $18.4 \pm 0.2^{\mathrm{ab}}$ & $18.4 \pm 0.1^{\mathrm{ab}}$ & $18.9 \pm 0.3^{\mathrm{ab}}$ & $18.0 \pm 0.4^{\mathrm{b}}$ \\
Crude lipid (\%) & $6.2 \pm 0.3$ & $6.6 \pm 0.3$ & $7.4 \pm 0.2$ & $5.8 \pm 0.4$ & $6.3 \pm 0.2$ & $6.2 \pm 0.5$ \\
Ash (\%) & $1.4 \pm 0.1$ & $1.4 \pm 0.1$ & $1.5 \pm 0.1$ & $1.5 \pm 0.1$ & $1.5 \pm 0.1$ & $1.7 \pm 0.2$ \\
\hline
\end{tabular}

\subsection{Secondary Continuing Trial}

There were no significant differences in gain, feed conversion, or mortality among any of the diets evaluated (Table 6). There was also no difference in individual fish length, weight, or conversion factor (Table 7). None of the fish health index components were different among the fish receiving the four diets as well.

\section{DISCUSSION}

The results indicate that PSG can replace at least 60\% of the fish meal without any negative repercussions on growth or feed conversion ratio. Unfortunately, these results cannot be directly compared to those described by Yamamoto et al. [32], who successfully eliminated fish meal from rainbow trout diets using fermented soybean meal. In addition to replacing the fish meal component with fermented soybean meal, Yamamoto et al. [32] also increased the corn gluten inclusion rate, while at the same time decreasing the percentage of wheat flour in the diets containing fermented soybean meal. Their control diet also contained $4.5 \%$ unfermented soybean meal. In contrast to Yamamoto et al. [32], during the current study both wheat flour and corn gluten were held constant at $15 \%$ in all of the diets; the control diet did not contain any soybean meal, and PSG directly replaced fish meal on a one-to-one basis. In addition, Yamamoto et al. [32] also supplemented their fermented soybean meal diets with multiple amino acids and conducted their study in much warmer water $(16.3 \mathrm{C})$. Water temperature can have an effect on nutritional observations [44-47].

It is extremely difficult to compare the growth results from this study with the numerous other studies using either soybean meal or soy protein concentrates. In many of these other studies, fish meal-based control diets were not used, or the concentrations of other non-soy protein sources were altered in the experimental diets [14-16,24, 48-53]. However, Barrows et al. [54] suggested that soybean meal replacement for fish meal should be limited to less than $25 \%$ (or $10 \%$ to $15 \%$ dietary inclusion rates). Hardy [55] stated that a maximum of $20 \%$ soybean meal can be included in the overall diets of rainbow trout, although this amount may be too high for smaller trout [19].

The significant decrease in growth and feed conversion ratio from the fish receiving diets with either $80 \%$ or $100 \%$ of the fish meal replaced by PSG was likely due to a large degree because of the lower dietary protein concentrations, as well as inadequate amounts of certain essential amino acids [56]. In particular, soybean meal typically does not have enough methionine to meet the nutritional requirements of rainbow trout [8,57]. Although PSG has slightly more methionine than soybean meal [58], it is still relatively low in comparison to that required in the diets of rainbow trout [59]. Yamamoto et al. [60] found that amino acid supplementation was required for their experimental diet containing soybean meal. Yamamoto et al. [32] supplemented fermented soybean meal diets with a number of essential amino acids. Methionine supplementation was done in other studies using soybean meal or soy protein concentrates in rainbow trout diets $[12,16,50]$.

Although specific feeding trial durations are not universally specified, they generally need to last long enough for any potential significant differences among the diets to materialize [61]. In a study by de Francesco et al. [62], differences in trout rearing performance between fish meal and plant-based diets did not become apparent until after 84 days. The initial trial in the present study lasted 70 days, but this was long enough for significant differences in gain and feed conversion ratio to become apparent at PSG inclusion levels over $40 \%$. When combined with the subsequent 40-day trial, the juvenile rainbow trout receiving up to $30 \%$ dietary PSG were on their respective dietary treatments for 110 days, which should have been long enough for any differences in rearing performance to appear.

The feed conversion ratios obtained for the diets containing less than $40 \%$ PSG in this study are typical for rainbow trout production in public hatcheries within South Dakota [34]. Other studies investigating plant proteins in trout diets have produced similar results. The commercial control diet used by Adelizi et al. [50] led to a feed conversion ratio of 0.89 , which was nearly identical 
Table 6. Rearing data (mean $\pm \mathrm{SE}$ ), including feed conversion ratio $\left(\mathrm{FCR}^{\mathrm{a}}\right)$, for tanks of rainbow trout receiving one of four different diets containing incremental amounts of PepSoyGen (PSG) for an additional 40 days after the conclusion of the primary trial $(\mathrm{N}=3$ ).

\begin{tabular}{lcccr}
\hline Diets & 1 & 2 & 3 & 4 \\
\hline PSG (\%) & 0 & 10 & 20 & 30 \\
End weight (g) & $5100 \pm 38$ & $5046 \pm 101$ & $5079 \pm 73$ & $5034 \pm 21$ \\
Gain (g) & $2380 \pm 38$ & $2326 \pm 101$ & $2359 \pm 73$ & $2314 \pm 21$ \\
Gain (\%) & $87.5+1.4$ & $85.5+3.7$ & $86.7+2.7$ & $85.1+0.8$ \\
Food fed (g) & 2155 & 2155 & 2155 & 2155 \\
FCR & $0.91 \pm 0.01$ & $0.93 \pm 0.04$ & $0.92 \pm 0.03$ & $0.92 \pm 0.01$ \\
Mortality (\%) & $0.00 \pm 0.00$ & $0.28 \pm 0.28$ & $0.00 \pm 0.00$ & $0.00 \pm 0.00$ \\
\hline
\end{tabular}

${ }^{\mathrm{a}} \mathrm{FCR}=$ feed conversion ratio $=$ total food fed/total weight gain.

Table 7. Mean $( \pm \mathrm{SE})$ total lengths, weights, and condition factors $\left(\mathrm{K}^{\mathrm{a}}\right)$ for rainbow trout receiving one of four different diets containing incremental amounts of PepSoyGen (PSG) for 40 days after the conclusion of the primary trial $(\mathrm{N}=3)$.

\begin{tabular}{lcccc}
\hline Diets & 1 & 2 & 3 & 4 \\
\hline PSG (\%) & 0 & 10 & 20 & 30 \\
Start weight (g) & $21 \pm 8.8$ & $26 \pm 8.1$ & $28 \pm 10$ & $70 \pm 9.4$ \\
End weight (g) & $74 \pm 6.2$ & $72 \pm 3.4$ & $133 \pm 15$ & $130 \pm 16$ \\
Start length (mm) & $120 \pm 17$ & $130 \pm 13$ & $184 \pm 6$ & $185 \pm 5$ \\
End length (mm) & $185 \pm 5$ & $186 \pm 4$ & $1.14 \pm 0.10$ & $1.12 \pm 0.10$ \\
Start K & $1.16 \pm 0.30$ & $1.15 \pm 0.07$ & $1.10 \pm 0.04$ & $1.10 \pm 0.02$ \\
End K & $1.13 \pm 0.02$ & $1.10 \pm 0.02$ & \\
\hline
\end{tabular}

${ }^{\mathrm{a}}$ Condition factor $(\mathrm{K})=10^{5} \times($ weight $) /\left(\right.$ length $\left.{ }^{3}\right)$.

to the 0.88 observed in this study. Barrows et al. [53] reported feed conversion ratios of 0.84 to 0.90 in a fish meal based diet containing 20\% soybean meal. Higher feed conversion ratios of 0.99 and 1.02 from soy beanfree, fish meal based diets were observed by Cheng et al. [51] and Cheng et al. [63], respectively. Cheng et al. [63] also reported ratios from 1.08 to 1.18 in diets with $8 \%$ soybean meal, $15 \%$ fish meal, and $16 \%$ wheat gluten, which were comparable to the 1.15 observed in the diets containing $40 \%$ PSG and $10 \%$ fish meal in this study.

None of the diets in this study produced any observable deleterious effects on fish health. In particular, no gross inflammation of the distal intestines of the fish receiving dietary PSG was observed in this study. However, microscopic examination did not occur. Yamamoto et al. [32] noted that lengthy and moist fermentation of soybean meal using Bacillus spp. could eliminate the occurrence of physiological abnormalities typically observed with the use of soybean meal in salmonid diets. PepSoyGen is manufactured by solid state fermentation (low moisture) which incorporates a growth medium based on feed grains rather than an artificial growth medium. The fermentation process hydrolyzes the long chain proteins into small chain proteins allowing them to be more suitable for young animal diets (relative to de-hulled soybean meal and other soy proteins). The fermentation process also clears the product of indigestible oligosaccharides (raffinose and stachyose) and trypsin inhibitor that can have a negative influence on gut health and nutrient digestibility. Although growth was not affected by up to $30 \%$ dietary PSG, this may not indicate a lack of intestinal damage. Bureau et al. [64] stated that fish growth is not necessarily inhibited by the changes in distal intestinal morphology caused by soybean meal.

The observed hepatosomatic index of 0.98 to 1.07 in rainbow trout fed diets containing up to $30 \%$ PSG is similar to that reported by Barrows et al. [53] and Panserat et al. [65] for rainbow trout fed fish meal or other plant-based diets. However, these values are much lower 
than those from other studies which fed soybean meal or other soybean products $[48,50,52,53]$. The only significant decrease in HSI observed in the current study was in the fish which received all of their protein from PSG. There was no increase in HSI with increasing amounts of PSG, as might be expected due to the positive relationship between HSI and carbohydrate levels [66,67]. The lack of difference in HSI among the diets would also appear to indicate no phosphorus availability limitations, given that dietary phosphorus is inversely related to liver lipid levels and HSI [68].

At $19.2 \%$, the fillet protein concentration from the control fish was identical to that from fish which received a commercial control diet in Adelizi et al. [50]. Among all of the diets evaluated in the current study, fillet protein was only significantly different in the trout receiving 50\% dietary PSG. Adelizi et al. [51] noted that fillet protein levels dropped to as low as $17.8 \%$ when soybean products were included in rainbow trout diets, although these values were not statistically significantly different from those obtained from fish fed a commercially-produced, fish meal-based control diet. Fillet protein concentrations were also similar to that reported by Yildiz [69], but less than that reported by Sealey et al. [70] from rainbow trout receiving a diet of $29 \%$ fish meal and $16 \%$ soybean meal.

\section{CONCLUSION}

The results from this study support the supposition of Yamamoto et al. [32] that fermented soybean meal is a promising ingredient as the main source of protein in rainbow trout diets. Further investigation is obviously needed to determine the extent, if any, of intestinal morphological changes that may be occurring with the inclusion of PSG in rainbow trout feeds. Trials involving ad libitum feeding should be conducted, as well as experiments with diets containing high concentrations of PSG modified to become isonitrogenous and isoenergetic to fish meal controls. In addition, amino acid supplementation should be examined as a possible mechanism to increase the amount of fish meal that can be successfully replaced by PSG without sacrificing trout growth.

\section{ACKNOWLEDGEMENTS}

The authors thank the South Dakota Soybean Research and Promotion Council, Agriculture Experiment Station, South Dakota State University, McNenny State Fish Hatchery, South Dakota Department of Game, Fish and Parks, and the North Central Agricultural Research Laboratory, USDA-ARS, Brookings, South Dakota, for funding, facilities, equipment, and supplies. Furthermore, the assistance of Rici Domenici, April Gregory, Erik Klinckman, Eric Krebs, Rilie Morgan, Patrick Nero, Sharon Nichols, Mehmet Tulbek, Jill Voorhees, Matt Wipf, Christine Wood, and Sarah Zimmerman is greatly appreciated.
This study was also funded, in part, by Nutraferma Inc. of North Sioux City, South Dakota.

\section{REFERENCES}

[1] Satia, B.P. (1974) Quantitative protein requirements of rainbow trout. Progressive Fish-Culturist, 36, 80-85. doi:10.1577/1548-8659(1974)36[80:QPRORT]2.0.CO;2

[2] Kim, K.I., Kayes, T.B. and Amundson, C.H. (1991) Purified diet development and reevaluation of the dietary protein requirement of fingerling rainbow trout. (Oncorhynchus mykiss). Aquaculture, 96, 57-67. doi:10.1016/0044-8486(91)90139-X

[3] Cheng, Z.J. and Hardy, R.W. (2004) Nutritional value of diets containing distiller's dried grain with solubles for rainbow trout, Oncorhynchus mykiss. Journal of Applied Aquaculture, 15, 101-113. doi:10.1300/J028v15n03 08

[4] Tacon, A.G.J. and Metian, M. (2008) Global overview of the use of fish meal and fish oil in industrially compounded aquafeeds: Trends and future prospects. Aquaculture, 285, 146-158. doi:10.1016/j.aquaculture.2008.08.015

[5] Food and Agricultural Organization of the United Nations (FAO) (2009) The state of the world fisheries and aquaculture. Food and Agriculture Organization, Rome. http://www.fao.org/docrep/011/i0250e/i0250e00.HTM.

[6] Hardy, R.W. (2010) Utilization of plant proteins in fish diets: Effects of global demand and supplies of fishmeal. Aquaculture Research, 41, 770-776. doi:10.1111/j.1365-2109.2009.02349.x

[7] Nordrum, S., Bakke-McKellep, A.M., Krogdahl, Á. and Buddington, R.K. (2000) Effects of soybean meal and salinity on intestinal transport of nutrients in Atlantic salmon (Salmo salar L.) and rainbow trout (Oncorhynchus mykiss). Comparative Biochemistry and Physiology, 125B, 317-335.

[8] Storebakken, T., Refstie, S. and Ruyter, B. (2000) Soy products as fat and protein sources in fish feeds for intensive aquaculture. In: Drackley, J.K., Ed., Soy in Animal Nutrition, Federation of Animal Science Societies, Champaign, 127-170.

[9] Krogdahl, Å., Berg-Lea, T. and Olli, J.J. (1994) Soybean proteinase inhibitors affect intestinal trypsin activities and amino acid digestibilities in rainbow trout (Oncorhynchus mykiss). Comparative Biochemistry and Physiology, 107A, 215-219. doi:10.1016/0300-9629(94)90296-8

[10] Arndt, R.E., Hardy, R.W., Sugiura, S.H. and Dong, F.M. (1999) Effects of heat treatment and substitution level on palatability and nutritional value of soy defatted flour for coho salmon, Oncorhynchus kisutch. Aquaculture, 180, 129-145. doi:10.1016/S0044-8486(99)00186-6

[11] Francis, G., Makker, H.P.S. and Becker, K. (2001) Antinutritional factors present in plant derived alternative fish feed ingredients and their effects on fish. Aquaculture, 199, 197-227. doi:10.1016/S0044-8486(01)00526-9

[12] Iwashita, Y., Yamamoto, T., Furuita, H., Sugita, T. and Suzuki, N. (2008) Influence of certain soybean antinutritional factors supplemented to a casein-based semi puri- 
fied diet on intestinal and liver morphology in fingerling rainbow trout Oncorhynchus mykiss. Fisheries Science, 74, 1075-1082. doi:10.1111/j.1444-2906.2008.01627.x

[13] Rumsey, G.L., Endres, J.G., Bowser, P.R., Earnest-Koons, K.A., Anderson, D.P. and Siwicki, A.K. (1995) Soy protein in diets of rainbow trout: Effects on growth, protein absorption, gastrointestinal histology and nonspecific seriologic and immune response. In: Lim, C.E. and Sessa, D.J., Eds., Nutrition and Utilization Technology in Aquaculture, AOCS Press, Urbana, pp. 166-188.

[14] Burrells, C., Williams, P.D., Southgate, P.J. and Crampton, V.O. (1999) Immunological, physiological and pathological responses of rainbow trout (Oncorhynchus mykiss) to increasing dietary concentrations of soybean proteins. Veterinary Immunology and Immunopathology, 72, 277288. doi:10.1016/S0165-2427(99)00143-9

[15] Heikkinen, J., Vielma, J., Kemiläinen, O., Tiirola, M., Eskelinen, P., Kiuru, T., Naiva-Paldanius, D. and von Wright, A. (2006) Effects of soybean meal based diet on growth performance, gut histopathology, and intestinal microbiota of juvenile rainbow trout (Oncorhynchus mykiss). Aquaculture, 261, 259-268. doi:10.1016/j.aquaculture.2006.07.012

[16] Barrows, F.T., Gaylord, T.G., Sealey, W.M., Haas, M.J. and Stroup, R.L. (2008) Processing soybean meal for biodiesel production: Effect of a new processing method on growth performance of rainbow trout, Oncorhynchus mykiss. Aquaculture, 283, 141-147.

doi:10.1016/j.aquaculture.2008.06.041

[17] Romarheim, O.H., Skrede, A., Gao, Y., Krogdahl, Á., Denstadli, V., Lilleeng, E. and Storebakken, T. (2008) Comparison of white flakes and toasted soybean meal partly replacing fish meal as protein source in extruded feed for rainbow trout (Oncorhynchus mykiss). Aquaculture, 256, 354-364.

doi:10.1016/j.aquaculture.2006.02.006

[18] Merrifield, D.L., Dimitroglou, A., Bradley, G., Baker, R.T.M. and Davies, S.J. (2009) Soybean meal alters autchthonous microbial populations, microvilli morphology and compromises intestinal enterocyte integrity of rainbow trout, Oncorhynchus mykiss (Walbaum). Journal of Fish Diseases, 32, 755-766. doi:10.1111/j.1365-2761.2009.01052.x

[19] Sealey, W.M., Barrows, F.T., Smith, C.E., Overturf, K. and LaPatra, S.E. (2009) Soybean meal level and probiotics in first feeding fry diets alter the ability of rainbow trout Oncorhynchus mykiss to utilize high levels of soybean meal during grow-out. Aquaculture, 293, 195-203. doi:10.1016/j.aquaculture.2009.04.013

[20] van den Ingh, T.S.G.A.M., Krogdahl, Å., Olli, J.J., Hendriks, H.G.C.J.M. and Koninkx, J.G.J.F. (1991) Effects of soybean-containing diets on the proximal and distal intestine in Atlantic salmon (Salmo salar): A morphological study. Aquaculture, 94, 297-305. doi:10.1016/0044-8486(91)90174-6

[21] Baeverfjord, G. and Krogdahl, Á. (1996) Development and regression of soybean meal induced enteritis in Atlantic salmon, Salmo salar L., distal intestine: A comparison with the intestines of fasted fish. Journal of Fish
Diseases, 19, 375-387.

doi:10.1111/j.1365-2761.1996.tb00376.x

[22] Bakke-McKellep, A.M., Press C. McL., Baeverfjord, G., Krogdahl, Á. and Landsverk, T. (2000) Changes in immune and enzyme histochemical phenotypes of cells in the intestinal mucosa of Atlantic salmon, Salmo salar L., with soybean meal-induced enteritis. Journal of Fish Diseases, 23, 115-127. doi:10.1046/j.1365-2761.2000.00218.x

[23] Bakke-McKellep, A.M., Penn, M.H., Salas, P.M., Refstie, S., Sperstad, S., Landsverk, T., Ringo, E. and Krogdahl, Å. (2007) Effects of dietary soyabean meal, inulin and oxytetracycline on intestinal microbiota and epithelial stress, apoptosis and proliferation in the teleost Atlantic salmon (Salmo salar L.). British Journal of Nutrition, 97, 699-713. doi:10.1017/S0007114507381397

[24] Gomes, E.F., Rema, P. and Kaushik, S.J. (1995) Replacement of fish meal by plant proteins in the diet of rainbow trout (Oncorhynchus mykiss): Digestibility and growth performance. Aquaculture, 130, 177-186. doi:10.1016/0044-8486(94)00211-6

[25] Barrows, F.T., Stone, D.A.J. and Hardy, R.W. (2007) The effects of extrusion conditions on the nutritional value of soybean meal for rainbow trout (Oncorhynchus mykiss). Aquaculture, 265, 244-252. doi:10.1016/j.aquaculture.2007.01.017

[26] Cheeke, P.R. and Shull, L.R. (1985) Natural toxicants in feeds and poisonous plants. AVI Publishing Company, Inc., Westport.

[27] Kim, S.S., Galaz, G.B., Pham, M.A., Jang, J.W., Oh, D.H., Yeo, I.K. and Lee, K.J. (2009) Effects of dietary supplementation of meju, fermented soybean meal, and Aspergillus oryzae for juvenile parrot fish (Oplegnathus fasciatus). Asian Australian Journal of Animal Sciences, 22, 849-856.

[28] Kader, M.A., Koshio, S., Ishikawa, M., Yokoyama, S., Bulbul, M., Honda, Y., Mamauag, R.E. and Laining, A. (2011) Growth, nutrient utilization, oxidative condition, and element composition of juvenile red sea bream $\mathrm{Pa}$ grus major fed with fermented soybean meal and scallop byproduct blend as fishmeal replacement. Fisheries Science, 77, 119-128. doi:10.1007/s12562-010-0312-9

[29] Lin, H., Chen, S., Chen, S., Zhuojia, L., Huang, Z., Niu, J., Wu, K. and Lu, X. (2011) Replacement of fish meal with fermented soybean meal in practical diets for pompano Trachinotus ovatus. Aquaculture Research, early view.

[30] Kim, S.S., Pham, M.A., Kim, K.W., Son, M.H. and Lee, K.J. (2010) Effects of microbial fermentation of soybean on growth performances, phosphorous availability, and antioxidant activity in diets for juvenile olive flounder (Paralichthys olivaceus). Food Science and Biotechnology, 19, 1605-1610. doi:10.1007/s10068-010-0227-3

[31] Kader, M.A., Koshio, S., Ishikawa, M., Yokoyama, S., Bulbul, M., Nguyen, B.T., Gao, J. and Laining, A. (2011) Can fermented soybean meal and squid by-product blend be used as fishmeal replacements for Japanese flounder (Paralichthys olivaceus)? Aquaculture Research, early view.

[32] Yamamoto, T., Iwashita, Y., Matsunari, H., Sugita, T., 
Furuita, H., Akimoto, A., Okamatsu, K. and Suzuki, N. (2010) Influence of fermentation conditions for soybean meal in a non-fish meal diet on the growth performance and physiological condition of rainbow trout Oncorhynchus mykiss. Aquaculture, 309, 173-180. doi:10.1016/j.aquaculture.2010.09.021

[33] Buterbaugh, G.L. and Willoughby, H. (1967) A feeding guide for brook, brown and rainbow trout. Progressive Fish Culturist, 29, 210-215. doi:10.1577/1548-8640(1967)29[210:AFGFBB]2.0.CO;2

[34] Barnes, M.E., Wintersteen, K., Krebs, E., Nero, P., Tycz, J., Reichert, S. and Zimmerman, S. (2011) 2010 McNenny state fish hatchery annual production report. South Dakota Department of Game, Fish and Parks Annual Report 11-03, South Dakota.

[35] Association of Official Analytical Chemists (AOAC) (2009) Official methods of for analysis, (online version), Maryland. http://www.eoma.aoac.org/

[36] American Association of Cereal Chemists (AACC) (2000) Approved methods of the American association of cereal chemists. 10th Edition, American Association of Cereal Chemists, St. Paul.

[37] National Research Council (NRC) (2011) Nutrient requirements of fish. National Academy Press, Washington DC.

[38] Goede, R.W. and Barton, B.A. (1990) Organismic indices and an autopsy-based assessment as indicators of health and condition in fish. In: Adam, S.M., Ed., Biological Indicators of Stress in Fish, American Fisheries Society, Symposium 8, Bethesda, 93-108

[39] Adams, S.M., Brown, A.M. and Goede, R.W. (1993) A quantitative health assessment index for rapid evaluation of fish condition in the field. Transactions of the American Fisheries Society, 122, 63-73. doi:10.1577/1548-8659(1993)122<0063:AQHAIF >2.3.C $\underline{\mathrm{O} ; 2}$

[40] Barton, B.A., Morgan, J.D. and Vijayan, M.M. (2002) Physiological and condition-related indicators of environmental stress in fish. In: Adams, S.M., Ed., Biological Indicators of Aquatic Ecosystem Stress, American Fisheries Society, Bethesda, 111-148.

[41] Strange, R.J. (1996) Field examination of fishes. In: Murphy, B.R. and Willis, D.W., Eds., Fisheries Techniques, 2nd Edition, American Fisheries Society, Bethesda, 433-466.

[42] Windell, J.T., Folz, J.W. and Sarokon, J.A. (1978) Methods of fecal collection and nutrient leaching in digestibility studies. Progressive Fish-Culturist, 40, 51-55. doi:10.1577/1548-8659(1978)40[51:MOFCAN]2.0.CO;2

[43] Kuehl, R.O. (2000) Design of experiments: Statistical principles of research design and analysis. 2nd Edition, Brookes/Cole, Belmont.

[44] Cowey, C.B., Degener, E., Tacon, A.G.J., Youngson, A. and Bell, J.G. (1984) The effect of vitamin E and oxidized fish oil on the nutrition of rainbow trout (Salmo gairdneri) grown at natural, varying water temperatures. British Journal of Nutrition, 51, 433-451. doi:10.1079/BJN19840050

[45] Alanärä, A. (1994) The effect of temperature, dietary energy content and reward level on the demand feeding activity of rainbow trout (Oncorhynchus mykiss). Aquaculture, 126, 349-359. doi:10.1016/0044-8486(94)90051-5

[46] Kim, J.D., Breque, J. and Kaushik, S.J. (1998) Apparent digestibilities of feed components from fish meal or plant protein based diets in common carp as affected by water temperature. Aquatic Living Resources, 11, 269-272. doi:10.1016/S0990-7440(98)80011-9

[47] Yamamoto, T., Suzuki, N., Furuita, H., Sugita, T., Tanaka, N. and Goto, T. (2007) Supplemental effect of bile salts to soybean meal-based diet on growth and feed utilization of rainbow trout Oncorhynchus mykiss. Fisheries Science, 73, 123-131. doi:10.1111/j.1444-2906.2007.01310.x

[48] Kaushik, S.J., Cravedi, J.P., Lalles, J.P., Sumpter, J., Fauconneau, B. and Laroche, M. (1995) Partial or total replacement of fish meal by soybean protein on growth, protein utilization, potential estrogenic or antigenic effects, cholesterolemia and flesh quality in rainbow trout, Oncorhynchus mykiss. Aquaculture, 133, 257-274. doi:10.1016/0044-8486(94)00403-B

[49] Refstie, S., Helland, S.J. and Storebakken, T. (1997) Adaptation to soybean meal in diets for rainbow trout, Oncorhynchus mykiss. Aquaculture, 153, 263-272. doi:10.1016/S0044-8486(97)00025-2

[50] Adelizi, P.D., Rosati, R.R., Warner, K., Wu, Y.V., Muench, T.R., White, M.R. and Brown, P.B. (1998) Evaluation of fish-meal free diets for rainbow trout, Oncorhynchus mykiss. Aquaculture Nutrition, 4, 255-262. doi:10.1046/j.1365-2095.1998.00077.x

[51] Cheng, Z.J., Hardy, R.W. and Usry, J.L. (2003) Effects of lysine supplementation in plant-protein diets on performance of rainbow trout (Oncorhynchus mykiss) and apparent digestibility coefficients of nutrients. Aquaculture, 215, 255-265. doi:10.1016/S0044-8486(02)00166-7

[52] Gaylord, T.G., Teague, A.M. and Barrows, F.T. (2006) Taurine supplementation of all-plant protein diets for rainbow trout (Oncorhynchus mykiss). Journal of the World Aquaculture Society, 37, 509-517. doi:10.1111/j.1749-7345.2006.00064.x

[53] Barrows, F.T., Gaylord, T.G., Sealey, W.M., Porter, L. and Smith, C.E. (2008) The effect of vitamin premix in extruded plant-based and fish-meal based diets on growth efficiency and health of rainbow trout, Oncorhynchus mykiss. Aquaculture, 283, 148-155. doi:10.1016/j.aquaculture.2008.07.014

[54] Barrows, F.T., Gaylord, T.G., Stone, D.A.J. and Smith, C.E. (2007) Effect of protein source and nutrient density on growth efficiency, histology, and plasma amino acid concentration of rainbow trout (Oncorhynchus mykiss Walbaum). Aquaculture Research, 38, 1747-1758.

[55] Hardy, R.W. (2002) Rainbow trout, Oncorhynchus mykiss. In: Webster, C.D. and Lim, C., Eds., Nutrient Requirements and Feeding of Aquaculture Fish, CAB International Publishers, New York, 184-202. doi:10.1079/9780851995199.0184

[56] Gatlin III, D.M., Barrows, F.T., Brown, P., Dabrowski, K., Gaylord, T.G., Hardy, R.W., Herman, E., Hu, G., Krogdahl, Å., Nelson, R., Overturf, K., Rust, M., Sealey, W., 
Skonberg, D., Souza, E., Stone, D., Wilson, R. and Wurtele, E. (2007) Expanding the utilization of sustainable plant products in aquafeeds - A review. Aquaculture Research, 38, 551-579. doi:10.1111/j.1365-2109.2007.01704.x

[57] Dabrowski, K., Poczyczynski, P., Kock, G. and Berger, B. (1989) Effect of partially or totally replacing fish meal protein by soybean meal protein on growth, feed utilization and proteolytic enzyme activities in rainbow trout (Salmo gardneri). New in vivo test for exocrine pancreatic secretion. Aquaculture, 77, 29-49. doi:10.1016/0044-8486(89)90019-7

[58] Stein, H.H. (2010) Nutrition advances benefit swine and the bottom line. Feed Management, 62, 10-13.

[59] Cowey, C.B, Cho, C.Y., Sivak, J.G., Weerheim, J.A. and Stuart, D.D. (1992) Methionine intake in rainbow trout (Oncorhynchus mykiss), relationship to cataract formation and the metabolism of methionine. Journal of Nutrition, 112, 1154-1163.

[60] Yamamoto, T., Shiima, T., Furuita, H. and Suzuki, N. (2002) Influence of feeding diets with and without fish meal by hand and by self-feeders on feed intake, growth and nutrient utilization of juvenile rainbow trout (Oncorhynchus mykiss). Aquaculture, 214, 289-305. doi:10.1016/S0044-8486(02)00035-2

[61] Weatherup, R.N. and McCraken, K.J. (1999) Changes in rainbow trout, Oncorhynchus mykiss (Walbaum), body composition with weight. Aquaculture Research, 30, 305307. doi:10.1046/j.1365-2109.1999.00320.x

[62] de Francesco, M., Parisi, G., Médale, F., Lupi, P., Kaushik, S.J. and Poli, B.M. (2004) Effect of long-term feeding with a plant protein mixture based diet on growth and body/fillet quality traits of large rainbow trout (Oncorhynchus mykiss). Aquaculture, 236, 413-429. doi:10.1016/j.aquaculture.2004.01.006

[63] Cheng, Z.J., Hardy, R.W. and Blair, M. (2003) Effects of supplementing methionine hydroxyl analogue in soybean meal and distiller's dried grain-based diets on the performance and nutrient retention of rainbow trout [On- corhynchus mykiss (Walbaum)]. Aquaculture Research, 34, 1303-1330. doi:10.1046/j.1365-2109.2003.00940.X

[64] Bureau, D.P., Harris, A.M. and Cho, C.Y. (1998) The effects of purified alcohol extracts from soy products on feed intake and growth of Chinook salmon and rainbow trout. Aquaculture, 161, 27-43. doi:10.1016/S0044-8486(97)00254-8

[65] Panserat, S., Hortopan, G.A., Plagnes-Juan, E., Kolditz, C., Lansard, M., Skiba-Cassy, S., Esquerré, D., Geurden, I., Médale, F., Kauskik, S. and Corraze, G. (2009) Differential gene expression after total replacement of dietary fish meal and fish oil by plant products in rainbow trout (Oncorhynchus mykiss) liver. Aquaculture, 294, 123-131. doi:10.1016/j.aquaculture.2009.05.013

[66] Daniels, W.H. and Robinson, E.H. (1986) Protein and energy requirements of juvenile red drum (Sciaenops ocellatus). Aquaculture, 53, 243-252. doi:10.1016/0044-8486(86)90354-6

[67] Kim, J.D. and Kaushik, S.J. (1992) Contributions of digestible energy from carbohydrates and estimation of protein/energy requirements for growth of rainbow trout (Oncorhynchus mykiss). Aquaculture, 106, 161-169. doi:10.1016/0044-8486(92)90200-5

[68] Sakamota, S. and Yone, Y. (1978) Effect of dietary phosphorus level on chemical composition of red sea bream. Bulletin of the Japanese Society of Scientific Fisheries, 44, 227-229. doi:10.2331/suisan.44.227

[69] Yildiz, M. (2004) The study of fillet quality and the growth performance of rainbow trout (Oncorhynchus mykiss) fed with diets containing different amounts of vitamin E. Turkish Journal of Fisheries and Aquatic Sciences, 4, 8186.

[70] Sealey, W.M., Gaylord, T.G., Barrows, F.T., Tomberlin, J.K., McGuire, M.A., Ross, C. and St.-Hilaire, S. (2011) Sensory analysis of rainbow trout, Oncorhynchus mykiss, fed enriched black soldier fly prepupae, Hermetia illucens. Journal of the World Aquaculture Society, 42, 34-45. doi:10.1111/j.1749-7345.2010.00441.x 